\title{
Pelaksanaan Asembling Rekam Medis di Rumah Sakit
}

\section{Implementation of Medical Record Asembling in Hospitals}

\author{
Henny Maria ulfa ${ }^{1}$ \\ Mutia Anzari ${ }^{2}$ \\ Risa Amalia ${ }^{3}$ \\ 1,2,3 STIKes Hang Tuah Pekanbaru \\ Jalan Mustafa Sari No 05 Tangkerang Selatan Pekanbaru \\ Email: hennyulfa84@gmail.com
}

\begin{abstract}
Assembling is an arrangement of medical records. Implementation of the assembling has not been well implemented at Hospitals owing to shortage of officers in medical records. So it is hard to know whether the medical records files are complete or not. The research done is to know the implementation of assembling at Hospitals. Type of research is descriptive qualitative. There are four informants. Data collection is by interview and observation. Data processing are triangulation technique and qualitative data analysis. The result of paper is obtained that implementation of assembling at Hospitals is only done at the time of accreditation of hospitals. As a result, there is no division of task for officers, officers having knowledge of implementation of assembling medical records are disturbed because of human resource and SPO of assembling medical records. It is wise that division of task and arrangement of SPO assembling medical records are made, officers' knowledge is improved by following seminar and training, and human resource is placed at assembling in order that implementation of assembling is carried out properly at Hospitals.
\end{abstract}

Keywords: Asembling, Medical Record document, hospital

\begin{abstract}
Abstrak
Assembling merupakan penataan rekam medis, pelaksanaan kegiatan asembling rekam medis di Rumah Sakit belum terlaksana dengan baik dikarenakan kekurangan petugas rekam medis yang bekerja di Rumah Sakit sehingga tidak bisa mengetahui apakah berkas rekam medis lengkap atau tidak. Penelitian ini untuk mengetahui pelaksanaan Assembling di Rumah Sakit. Jenis penelitian adalah deskriptif kualitatif. Informan dalam penelitian berjumlah 4 orang. Teknik pengumpulan data dengan wawancara dan observasi. Pengolahan data dilakukan dengan teknik triagulasi, analisis data dengan analisis kualitatif. Hasil penelitian ini diperoleh bahwa pelaksaaan assembling dilakukan pada saat ingin akreditasi rumah sakit, sehingga belum ada uraian tugas petugas assembling rekam medis, petugas mempunyai pengetahuan dalam pelaksanaan assembling rekam medis namun untuk melaksanakannya terkendala pada sumber daya yang kurang dan belum memiliki SPO assembling rekam medis di unit rekam medis Rumah Sakit. Sebaiknya dibuatkan uraian tugas petugas dan SPO assembling rekam medis, pengetahuan petugas assembling rekam medis ditingkatkan dengan mengikuti seminar dan pelatihan rekam medis dan menempatkan sumber daya manusia di bagian assembling supaya pelaksanaan assembling terlaksana dengan optimal di Rumah Sakit.
\end{abstract}

Kata Kunci: Asembling, Rekam Medis, rumah sakit

\section{A. Pendahuluan}

Upaya kesehatan adalah setiap kegiatan dan/atau serangkaian kegiatan yang dilakukan secara terpadu, terintegrasi dan berkesinambungan untuk memelihara dan meningkatkan derajat kesehatan masyarakat dalam bentuk pencegahan penyakit, peningkatan kesehatan, pengobatan penyakit, dan pemulihan kesehatan oleh pemerintah dan/atau masyarakat (Undang-Undang RI No. 36 tahun 2009). Upaya kesehatan tersebut didalam pelayanan kesehatan paripurna yaitu pelayanan kesehatan yang meliputi promotif, preventif, kuratif, dan rehabilitatif. Rumah Sakit mempunyai tugas memberikan pelayanan kesehatan 
perorangan secara paripurna (UU RI No. 44 Tahun 2009).

Rumah Sakit adalah institusi pelayanan kesehatan yang menyelenggarakan pelayanan kesehatan perorangan secara paripurna yang menyediakan pelayanan rawat inap, rawat jalan, dan gawat darurat. Penyelenggaraan Rumah Sakit bertujuan meningkatkan mutu dan mempertahankan standar pelayanan rumah sakit dan setiap rumah sakit mempunyai kewajiban menyelenggarakan rekam medis (UU RI No. 44 Tahun 2009).

Menurut Permenkes No. 269/MENKES/PER/III/2008 tentang rekam medis adalah berkas yang berisi catatan dan dokumen antara lain identitas pasien, hasil pemeriksaan, pengobatan yang telah diberikan, serta tindakan dan pelayanan yang telah diberikan kepada pasien. Pengolahan berkas rekam medis dimulai dari tempat penerimaan pasien (membuat atau menyiapkan berkas rekam medis), dilanjutkan dengan assembling, coding, indexing dan filling. Assembling bearti merakit, tetapi untuk kegiatan assembling berkas rekam medis di fasilitas pelayanan kesehatan tidaklah hanya sekedar merakit atau mengurut satu persatu halaman ke halaman yang lain sesuai dengan aturan yang berlaku. Pengurutan halaman ini dimulai dari berkas rekam medis rawat darurat, rawat jalan dan rawat inap dan pergantian pada masing-masing pelayanan akan diberikan kertas pembatas yang menonjol sehingga dapat mempermudah pencarian formulir dalam berkas rekam medis (Budi, 2011).

Unit rekam medis terdapat bagian assembling yang memiliki peran penting meliputi sebagai peneliti kelengkapan isi dan perakit dokumen rekam medis sebelum disimpan, menerima dokumen rekam medis dan mencatat di buku register semua rekam medis yang masuk dan keluar atau disebut juga sensus harian dari unit pelayanan, mencatat dan mengendalikan dokumen rekam medis yang isinya belum lengkap dan secara periodik. Oleh karena itu pelaksaan unit assembling sangat penting karena dapat dijadikan tolak ukur mutu berkas rekam medis di fasilitas rekam medis di fasilitas pelayanan kesehatan.

Berdasarkan wawancara survey awal yang dilakukan pada unit rekam medis di Rumah Sakit dalam assembling rekam medis belum terlaksana dikarenakan kekurangan petugas rekam medis yang bekerja di Rumah Sakit. Tidak terlaksananya kegiatan assembling rekam medis mengakibatkan tidak terkendalinya formulir rumah sakit, dalam kata lain petugas tidak bisa mengetahui apakah berkas rekam medis tersebut telah lengkap atau tidak, telah terjadi kesalahan apa tidak, hal ini pula mengakibatkan kurang valid dalam pelaksanaan sensus berkas pulang oleh petugas rekam medis. Padahal kegiatan assembling dapat mengetahui kelengkapan pengisian rekam medis yang apabila ditemukan berkas yang tidak lengkap akan dilaporkan kepada kepala unit rekam medis mengenai ketidaklengkapan isi dokumen dan petugas yang bertanggung jawab terhadap kelengkapan isi tersebut, Assembling juga mengendalikan penggunaan formulir rekam medis dan secara periodik.

\section{B. Metode}

Jenis penelitian ini adalah penelitian kualitatif dengan tujuan untuk mengetahui bagaimana gambaran pelaksanaan assembling di Rumah Sakit. Lokasi penelitian dilaksanakan di Rumah Sakit, 4 orang informen penelitian. Variabel penelitian terdiri dari urain tugas, pengetahuan petugas terhadap assembling dan SPO assembling. Instrumen penelitian untuk pengumpulan data adalah pedoman observasi, wawancara, alat perekam dan alat tulis. Pengumpulan data dilakukan dengan observasi dan wawancara, sumber data menggunakan primer dan sekunder, 
pengolahan data menggunakan teknik non statistic dengan teknik triangulasi untuk pemeriksaan keabsahan yaitu teriangulasi dengan sumber, teringulasi dengan metode dan triangulasi dengan data. Analisa data dalam penelitian ini adalah teknik analisis kualitatif, dalam teknik digunakan proses induktif.

\section{Hasil dan Pembahasan}

\section{Uraian Tugas Petugas Rekam Medis Di Rumah Sakit}

Berdasarkan hasil penelitian mengenai uraian tugas petugas assembling rekam medis di Rumah Sakit yakni Pembagian tugas rekam medis di Rumah Sakit sesuai dengan kebijakan rumah sakit, jika pihak rumah sakit merasa diperlukannya tenaga disalah satu bagian maka akan ditarik petugas dari ruangan lain yang berlebih agar dipindah keruangan yang membutuhkan tersebut. Sampai saat ini belum melakukan pemantauan terhadap assembling rekam medis dan belum optimalnya kegiatan assembling rekam medis dikarenakan kegiatan assembling rekam medis dilakukan pada saat ingin akreditasi rumah sakit dan kegiatan tersebut dibantu oleh petugas yang lain. Petugas di unit rekam medis berjumlah 1 orang petugas rekam medis tamatan DIII rekam medis yang merangkap berbagai tugas pokok fungsi seperti pendaftaran, pengambilan dan pengantaran berkas rekam medis, pembuatan SEP dan rujukan, sehingga membuat petugas tersebut kewalahan dan mengakibatkan kegiatan assembling rekam medis menjadi tidak dapat terlaksana. belum ada uraian tugas petugas pada kegiatan assembling rekam medis.

Uraian tugas adalah tugas yang harus dilakukan oleh setiap karyawan dalam organisasi, sesuai dengan jabatan atau pekerjaan karyawan yang bersangkutan. Oleh sebab itu uraian tugas yang sudah ada dijadikan sebagai acuan jenis kegiatan atau tugas yang terdapat dalam organisasi dan yang harus dikerjakan oleh masingmasing petugas (Notoadmodjo, 2010).

Menurut Notoadmodjo (2009) dalam uraian tugas suatu organisasi yang berkaitan dengan penilaian prestasi kerja karyawan, sekurang-kurangnya mencakup 3 hal, yakni :

a. Kewajiban yang harus dilaksanakan oleh pelaksana pekerjaan (Karyawan).

b. Tanggung jawab yang dibebankan kepada pelaksana pekerjaan tertentu.

c. Persyaratan yang harus dipenuhi.

Oleh sebab itu, maka uraian tugas itu harus disusun sebaik-baiknya dan sejelasjelasnya, sehingga para pelaksana tugas juga jelas melaksanakannya, dan penilai juga jelas dalam melakukan penilaian.

Bagian assembling yaitu salah satu bagian di unit rekam medis yang mempunyai tugas pokok yaitu:

a. Merakit kembali DRM dari rawat jalan, gawat darurat dan rawat inap menjadi urutan atau runtut sesuai dengan kronologi penyakit pasien yang bersangkutan.

b. Meliputi kelengkapan data yang seharusnya tercatat di dalam formulir rekam medis sesuai dengan kasus penyakitnya.

c. Meneliti kebenaran pencatatan data rekam medis sesuai dengan kasus penyakitnya.

d. Mengendalikan DRM yang dikembalikan ke unit pencatatan data karena isinya tidak lengkap

e. Mengendalikan penggunaan nomor rekam medis.

f. Mendistribusikan dan mengendalikan penggunaan formulir rekam medis (Sudra, 2017).

Peran dan fungsi assembling dalam pelayanan rekam medis yaitu sebagai perakit formulir rekam medis, peneliti isi data rekam medis, pengendalian DRM tidak lengkap, pengendali penggunaan nomor rekam medis dan formulir rekam medis. 
Berdasarkan hasil penelitian dan teori yang mendukung maka penulis berpendapat bahwa uraian tugas dalam pelaksanaan assembling rekam medis perlu dibuat karena peran dan fungsi assembling dalam pelayanan rekam medis yaitu sebagai perakit formulir rekam medis, peneliti isi data rekam medis, pengendalian DRM tidak lengkap, pengendali penggunaan nomor rekam medis dan formulir rekam medi.

Disusun sejelas-jelasnya sebagai acuan yang jelas untuk para petugas dalam melaksanakan pekerjaan yang dikaitkan dengan penilaian prestasi kerja petugas assembling rekam medis di Rumah Sakit

\section{Pengetahuan Petugas Terhadap Assembling Rekam Medis Di Rumah Sakit}

Berdasarkan hasil penelitian yang dilakukan tentang pengetahuan petugas terhadap assembling rekam medis di Rumah Sakit yakni petugas mempunyai pengetahuan mengetahui pelaksanaan assembling rekam medis, namun untuk melaksanakannya terkendala pada SDM yang kurang. Belum pernah mengikuti seminar dan pelatihan tentang assembling rekam medis dikarenakan biaya mengikuti seminar dan pelatihan yang mahal.

Pengetahuan (knowledge) adalah hasil tahu dari manusia yang sekedar menjawab pertanyaan"what". Pengetahuan adalah hasil penginderaan manusia atau hasil tahu seseorang terhadap objek melalui indera yang dimilikinya (mata, hingga, telingga dan sebagainya). Dengan sendirinya pada waktu penginderaan hingga menghasilkan pengetahuan tersebut sangat dipengaruhi oleh intensitas perhatian dan presepsi terhadap objek (Notoadmodjo, 2009).

Terdapat dua aspek yang dilihat dalam sumber daya manusia yakni : a. Kuantitas, yaitu menyangkut jumlah sumberdaya manusia

b. Kualitas, yaitu menyangkut mutu sumber daya manusia tersebut, yang menyangkut kemampuan fisik maupun kemampuan non fisik (kecerdasan dan mental). Untuk meningkatkan kualitas fisik dapat di upayakan program-program kesehatan dan gizi. Sedangkan untuk meningkatkan kemampuan non fisik dapat diupayakan dengan pelatihan dan pendidikan. Pelatihan adalah suatu kegiatan peningkatan kemampuan karyawan atau pegawai dalam suatu institusi, sehingga pelatihan dapat diartikan suatu proses yang dapat menghasilkan suatu perubahan perilaku bagi karyawan atau pegawai (Notoatmodjo, 2009).

Berdasarkan hasil penelitian dan teori yang mendukung maka penulis berpendapat bahwa petugas assembling rekam medis di Rumah Sakit dilihat dari dua aspek yaitu kuantitas yang menyangkut dengan jumlah petugas assembling rekam medis, kualitas menyangkut mutu petugas assembling rekam medis baik kemampuan fisik dan don fisik salah satunya dengan pelatihan dan pendidikan sesuai kompetensi rekam medis sehingga pelaksanaan assembling rekam medis dapat dilaksanakan dengan optimal untuk bisa meningkatkan mutu rekam medis di Rumah Sakit.

\section{SPO Assembling Rekam Medis di Rumah Sakit}

Berdasarkan hasil penelitian yang dilakukan tentang SPO assembling rekam medis di Rumah Sakit yakni belum ada dibuat SPO assembling rekam medis di unit rekam medis Rumah Sakit hanya melihat dari Depertemen Kesehatan aja. Kebijakan dari rumah sakit belum ada, karena setiap petugas bisa melaksanakan sampai 3 tanggung jawab, karena kekurangan SDM, minta tambah personil tapi belum 
didukung, harus manfaatkan personil yang ada.

SPO pada dasarnya adalah pedoman yang berisi prosedur-prosedur operasional standar yang ada didalam suatu organisasi yang digunakan untuk memasukan bahwa setiap keputusan, langkah, atau tindakan, ada penggunaan fasilitas pemprosesan yang dilaksanakan oleh orang-orang di dalam suatu organisasi, telah berjalan secara efektif, konsisten, standar dan sistematis (Tambunan, 2013).

Peran dan manfaat Standar Prosedur Operasional pedoman di dalam suatu organisasi

a. Menjadi pedoman kebijakan yang merupakan dasar bagi seluruh kegiatan organisasi, secara operasional maupun administratif (pedoman kebijakan)

b. Menjadi pedoman kegiatan-kegiatan organisasi, baik secara operasional maupun administratif (pedoman kegiatan)

c. Menjadi pedoman untuk memvalidasi langkah-langkah kegiatan dalam organisasi (pedoman birokrasi)

d. Menjadi pedoman terkait penggunaan formulir, dokumen, blanko, dan laporan yang digunakan kedalam kegiatan-kegiatan organisasi (pedoman administrasi) (Tambunan, 2013).

SPO assembling rekam medis dalam proses pengolahan rekam medis terbagi beberapa bagian yaitu penataan berkas Rekam Medis pasien rawat jalan, Penataan Berkas Rekam Medis Pasien Rawat Inap untuk kasus Anak, Penataan Berkas Rekam Medis Pasien Rawat Inap kasus Bedah, Penataan Berkas Rekam Medis Pasien Rawat Inap Kasus Kebidanan, Penataan Berkas Rekam Medis Pasien Rawat Inap kasus Bayi Baru Lahir (Depkes RI, 2006).

Berdasarkan hasil penelitian dan teori yang mendukung maka penulis berpendapat bahwa SPO assembling rekam medis perlu dibuat karena pada dasarnya sebagai pedoman berisikan prosedur-prosedur operasional standar dalam assembling rekam medis dengan salah satu manfaatnya menjadi pedoman kebijakan dalam kegiatan-kegiatan khususnya SPO assembling dalam proses pengolahan rekam medis yang terbagi beberapa bagian dari assembling rekam medis yang ada di Rumah Sakit.

\section{Simpulan dan Saran}

Belum adanya uraian tugas petugas assembling rekam medis di Rumah Sakit sehingga pelaksanaan assembling belum optimal dikarena belum adanya petugas assembling rekam medis. petugas sebenarnya mempunyai pengetahuan tentang pelaksanaan assembling rekam medis, belum ada sumber daya manusia yang ditempatkan dibagian assembling rekam medis, belum ada dibuat SPO assembling rekam medis hanya melihat dari Depertemen Kesehatan Republik Indonesia.

\section{E. Ucapan Terima Kasih}

Terimakasih kami sampaikan kepada Direktur Rumah Sakit beserta jajarannya serta petugas Unit Kerja Rekam Medis yang telah membantu mensukseskan penelitian ini.

\section{F. Dafatar Pustaka}

Budi, S.C. (2011). Manajemen Unit Kerja Rekam Medis. Yogyakarta: Quantum Sinergis Media.

Depkes, RI. (2006). Pedoman Penyelenggaraan dan Prosedur Rekam Medis Rumah Sakit di Indonesia, Jakarta: DIRJEN YANMED.

Sudra, R. I (2017), Rekam Medis. Banten: Universitas Terbuka.

Moleong, (2016). Metodologi Penelitian Kualitatif. Bandung: PT Remaja Rosdakarya. 
Notoatdmojo S, (2007). Promosi Kesehatan Dan Ilmu Prilaku. Jakarta: PT Rineka Cipta.

Peraturan Menteri Kesehatan (PERMENKES) Nomor 269/MENKES/PER/III/2008 tentang Rekam Medis. Jakarta Sugiyono. (2014). Metode Penelitian Pendidikan pendekatan kuantitatif, kualitatif dan RED. Bandung: Alfabeta.
Tambunan, (2013). Standard Operasional Prosedur. Jakarta: PT Suka Buku.

UU RI Nomor 44 Tahun 2009 Tentang Rumah Sakit. 2012. Bandung: Citra Umbara.

UU RI Nomor 36 Tahun 2009 Tentang Kesehatan. Jakarta. 